\title{
Prevalence of Depression among Pregnant Women with Hyperemesis Gravidarum in Thi-Qar Maternity Hospitals, 2016
}

\author{
Manar Najim Abd* \\ Alaa Hussein Ali Al Nasir ** alaa-h@utq.edu.iq \\ Ahmed Hassan Hussein** ahmed-hassan@utq.edu.iq \\ *Al-Hussein Teaching Hospital / Thi-Qar Directorate of Health \\ ** Thi-Qar University / College of Medicine
}

\begin{abstract}
Background: Globally, depression is considered as the first leading cause of disease burden in women at child bearing age (15-44year). Nationally, scarce information was published regarding the prevalence of depression in pregnant women with hyperemesis gravidarum.
\end{abstract}

Objectives: This study was carried out to measure the prevalence of depression among pregnant women with hyperemesis gravidarum in Thi-Qar Maternity hospitals.

Materials and methods: A hospital based cross sectional study was carried out in two teaching hospitals in Thi-Qar Maternity hospitals from first of Sep 2015 to $31^{\text {st }}$ of Jul 2016. All pregnant women who were suffering from hyperemesis gravidarum, and attended the obstetric outpatients in these two hospitals were included. Based on assumed prevalence of depression among pregnant women in a previous study in Iraq was $(37.2 \%)$, so the needed sample size to calculate such prevalence with precision of $5 \%$, confidence level of $95 \%$, and added extra sample of $10 \%$, was almost equal to 322. Women data were collected by using Arabic version of Beck depression inventory-II and specialized questionnaire which was designed for the purpose of the study. Depression considered when patients had Beck depression inventory-II score of $>20$.

Results: this study showed that prevalence rate of depression among pregnant women with hyperemesis gravidarum was $37.1 \%$. This rate was significantly affected by increased gestational age $(\mathrm{P}=0.003)$, high socioeconomic status $(\mathrm{P}=0.009)$, previous history of hyperemesis $(\mathrm{P}=0.03)$, unwanted pregnancy $(\mathrm{P}=0.03)$, and increased gravidity $(\mathrm{P}=0.03)$. 
Conclusions: one-third of pregnant women with hyperemesis gravidarum in Thi-Qar Maternity hospitals had depression. It is recommended to reinforce mental health care of pregnant women through the antenatal care services at primary health care level, with strengthening the mental and social rehabilitation method that were used for diagnosed women with depression.

Key words: Depression, pregnant, hyperemesis gravidarum, Thi-Qar Maternity hospitals.

\section{Introduction}

Hyperemesis gravidarum is known as the severe intractable form of nausea and vomiting during early pregnancy, affecting $0.5 \%-2 \%$ of pregnant women. ${ }^{1,2,3}$

Globally, the first leading cause of disease burden in women at child bearing age is depression. ${ }^{4}$ Depression is a common and serious mental disorder that negatively affects how you feel, the way you think and how you act, accompanied by low selfesteem and loss of interest or pleasure in normally enjoyable activities. ${ }^{5}$ Depression earned its global public health importance from its higher rate during pregnancy ${ }^{6}$ and its impact on the health of both mother and fetus. ${ }^{7}$ Depressed pregnant women have 3.4 times risk of preterm delivery, 4.0 times risk of low birth weight baby, and higher rates of maternal suicide. ${ }^{8}$ Prevalence of depression in pregnant women ranged from $7.4 \%$ to $51.4 \%$. It varies in different stages of pregnancy, ranging from $7.4 \%-24.6 \%$ in first trimester, $9.1 \%-48.9 \%$ in second trimester, and $8.8 \%-51.4 \%$ in third trimester. ${ }^{9}$ Women have twice risk of experiencing depression than men. ${ }^{10}$
Furthermore, women during pregnancy, and postpartum periods are more likely to develop depression than any other time in their lives. ${ }^{11}$

Nationally, scarce information was published regarding the prevalence of depression in pregnant women with hyperemesis gravidarum. ${ }^{12}$ This study was carried out to measure the prevalence of depression among pregnant women with hyperemesis gravidarum in Thi-Qar Maternity hospitals.

\section{Subjects \& Methods}

A hospital based cross sectional study was carried out in two hospitals (Al Habobi teaching hospital and Bent Al Huda teaching hospital) in Thi- Qar province from first of Sep 2015 to 31st of Jul 2016.

All eligible pregnant women who were suffering from severe vomiting (> 3 times/day) without any other obvious underlying cause and were unable to maintain oral uptake with $>3 \mathrm{Kg}$ weight loss, and positive ketone urea, and who were attending the obstetric outpatient of the two hospitals were recruited for this study. Pregnant women with 


\section{Email:utjmed@utq.edu.iq}

evidence of antenatal bleeding, with mild to moderate nausea and vomiting, preexisting medical or psychiatric comorbid conditions, patient refused to participate, and those using antibiotic, proton pump inhibitor, and $\mathrm{H} 2$ blocker at time of inclusion were excluded from this study.

An appropriate sample size was calculated by applying the following equation ${ }^{13}: \mathrm{n}=\left(\mathrm{z}^{2} \mathrm{pq}\right) / \mathrm{d}^{2}$, Based on assumed prevalence of depression among pregnant women in a previous study in Iraq was (37.2\%), so the needed sample size to calculate such prevalence rate with precision of 5\%, confidence level of $95 \%$, and added extra sample of $10 \%$ after adjustment according to target of pregnant women (4\%) in Thi-Qar province, was almost equal to 322 .

Women data were collected by the researcher by using two sets of questionnaires. The $1^{\text {st }}$ is the Arabic version of standard Beck depression inventory questionnaireII, ${ }^{14}$ and the $2^{\text {nd }}$ is a specialized questionnaire which was designed for the purpose of the study. Beck depression inventory (BDI) consist of (21) questions, with a scoring ranging from 0-3 for each question. A total scoring of 1-10 is considered normal, $11-16$ is considered mild mood disturbance, $17-20$ is considered borderline clinical depression, 21-30 is considered moderate depression, $31-40$ is considered severe depression, and over 40 is considered extreme depression. A total BDI score of $>20$ is considered as depression. The $2^{\text {nd }}$
Web Site: https://jmed.utq.edu.iq

questionnaire includes different variables that are suspected to be associated with the rate of depression among enrolled participants.

All collected data were entered in to computerized statistical software; Statistical Package for Social Sciences (SPSS) version 23 was used. Descriptive statistics were presented as (mean \pm standard deviation) and frequencies as percentages. Multiple contingency tables were conducted and appropriate statistical tests are performed, Chi-square was used for categorical variables and Fishers exact test was used when more than $20 \%$ of expected variable was less than 5. t-test analysis was used to compare between means. In all statistical analysis, the level of significance ( $\mathrm{p}$ value) sets at $\leq 0.05$ and the result were shown as tables.

\section{Results}

$\begin{array}{lcc}\text { A total of } 313 \text { pregnant } \\ \text { women } & \text { with } & \text { hyperemesis } \\ \text { gravidarum } & (\mathrm{HG}) & \end{array}$
included in the present study, the refused rate was $(2.8 \%)$. The mean age of included women was $27.1 \pm 6.3$ years. A mean BDI score of HG was 20 \pm 12 . Generally, depression prevalence among pregnant women with hyperemesis gravidarum was $37.1 \%$ as shown in Table No1. This rate was significantly affected $(\mathrm{P}=$ 0.009 ) by high socioeconomic status of the study participants as shown in Table No2. HG pregnant women with increased gestational age at the study time were significantly had 
Email:utjmed@utq.edu.iq

higher depression prevalence $(\mathrm{P}=$ 0.03), this was shown in Table No3. HG pregnant women with previous history of $\mathrm{HG}$ in previous pregnancies and $\mathrm{HG}$ pregnant women who were unwanted this pregnancy had significantly higher depression prevalence $(\mathrm{p}=0.03$ on
Web Site: https://jmed.utq.edu.iq

both) as shown in Figure No1. Socioeconomic score mean and gravida mean were significantly higher $(\mathrm{p}=0.001$ and 0.03 respectively) among depressed pregnant than non-depressed pregnant as shown in Table No4.

Table 1. Beck Depression Inventory score and depression distribution of Hyperemesis Gravidarum women.

\begin{tabular}{|l|c|c|}
\hline Variable & No. & \% \\
\hline BDI score: Mean \pm SD $(\mathbf{2 0} \pm \mathbf{1 2})$ & \multicolumn{2}{|c|}{} \\
\hline Normal & 64 & 20.4 \\
\hline Mild mood disturbances & 72 & 23.0 \\
\hline Borderline clinical & 61 & 19.5 \\
\hline Moderate depression & 49 & 15.7 \\
\hline Severe depression & 31 & 9.9 \\
\hline Extreme depression & 36 & 11.5 \\
\hline Total & 313 & 100.0 \\
\hline Depression & & \\
\hline Yes & 116 & 37.1 \\
\hline No & 197 & 62.9 \\
\hline Total & 313 & 100.0 \\
\hline
\end{tabular}


Table 2. Distribution of sociodemographic characteristics and socioeconomic status of Hyperemesis Gravidarum women according to depression status.

\begin{tabular}{|c|c|c|c|c|c|c|}
\hline \multirow[t]{2}{*}{ Variable } & \multicolumn{2}{|c|}{ Depression } & \multicolumn{2}{|c|}{ No } & \multirow[t]{2}{*}{$\chi^{2}$} & \multirow[t]{2}{*}{$\mathbf{P}$} \\
\hline & No. & $\%$ & No. & $\%$ & & \\
\hline \multicolumn{5}{|c|}{ Age: mean \pm SD $(27.1 \pm 6.3$ years $)$} & \multirow[t]{5}{*}{1.7} & \multirow[t]{5}{*}{0.6} \\
\hline$<20$ years & 11 & 33.3 & 22 & 66.7 & & \\
\hline 20-29 years & 67 & 39.4 & 103 & 60.6 & & \\
\hline 30-39 years & 32 & 33.0 & 65 & 67.0 & & \\
\hline$\geq 40$ years & 6 & 46.2 & 7 & 53.8 & & \\
\hline \multicolumn{5}{|l|}{ Occupation } & \multirow[t]{6}{*}{5.8} & \multirow[t]{6}{*}{$0.2^{*}$} \\
\hline Housewife & 87 & 34.7 & 164 & 65.3 & & \\
\hline $\begin{array}{l}\text { Sciences and } \\
\text { engineering } \\
\text { professional }\end{array}$ & 5 & 31.3 & 11 & 68.8 & & \\
\hline Health professional & 10 & 58.8 & 7 & 41.2 & & \\
\hline Teaching & 12 & 48.0 & 13 & 52.0 & & \\
\hline Student & 2 & 50.0 & 2 & 50.0 & & \\
\hline \multicolumn{5}{|l|}{ Residence } & \multirow[t]{3}{*}{1.5} & \multirow[t]{3}{*}{0.2} \\
\hline Urban & 85 & 39.4 & 131 & 60.6 & & \\
\hline Rural & 31 & 32.0 & 66 & 68.0 & & \\
\hline \multicolumn{5}{|l|}{ Educational level } & \multirow[t]{5}{*}{5.9} & \multirow[t]{5}{*}{0.1} \\
\hline Illiterate & 22 & 46.8 & 25 & 53.2 & & \\
\hline Primary level & 34 & 36.2 & 60 & 63.8 & & \\
\hline Secondary level & 26 & 28.6 & 65 & 71.4 & & \\
\hline College/institute & 34 & 42.0 & 47 & 58.0 & & \\
\hline \multicolumn{5}{|c|}{ Socioeconomic status: Mean \pm SD $(3.8 \pm 0.9)$} & \multirow[t]{4}{*}{9.4} & \multirow[t]{4}{*}{0.009} \\
\hline Low & 6 & 26.1 & 17 & 73.9 & & \\
\hline Moderate & 70 & 33.0 & 142 & 67.0 & & \\
\hline High & 40 & 51.3 & 38 & 48.7 & & \\
\hline
\end{tabular}

*Fisher Exact test. 
Table 3. Distribution of gestational characteristics of Hyperemesis Gravidarum women according to depression status.

\begin{tabular}{|c|c|c|c|c|c|c|}
\hline \multirow[t]{2}{*}{ Variable } & \multicolumn{2}{|c|}{ Depression } & \multicolumn{2}{|c|}{ No depression } & \multirow[t]{2}{*}{$\chi^{2}$} & \multirow[t]{2}{*}{$\mathbf{P}$} \\
\hline & No. & $\%$ & No. & $\%$ & & \\
\hline \multicolumn{5}{|c|}{ Gravida: Mean \pm SD $(3 \pm 2)$} & \multirow[t]{3}{*}{0.1} & \multirow[t]{3}{*}{0.6} \\
\hline Prime & 22 & 34.9 & 41 & 56.1 & & \\
\hline Multi & 94 & 37.6 & 156 & 62.4 & & \\
\hline \multicolumn{5}{|c|}{ Parity: Mean \pm SD $(2 \pm 1)$} & \multirow[t]{4}{*}{3.7} & \multirow[t]{4}{*}{0.1} \\
\hline No & 27 & 39.1 & 42 & 60.9 & & \\
\hline 1 & 44 & 31.4 & 96 & 68.6 & & \\
\hline$\geq 2$ & 45 & 43.3 & 59 & 56.7 & & \\
\hline \multicolumn{5}{|c|}{ miscarriage number: Mean \pm SD $(1 \pm 1)$} & \multirow[t]{4}{*}{2.3} & \multirow[t]{4}{*}{0.3} \\
\hline No & 79 & 34.8 & 148 & 65.2 & & \\
\hline 1 & 23 & 40.4 & 34 & 59.6 & & \\
\hline$\geq 2$ & 14 & 48.3 & 15 & 51.7 & & \\
\hline \multicolumn{5}{|c|}{ Gestational age at time of interview: Mean \pm SD } & \multirow[t]{3}{*}{4.3} & \multirow[t]{3}{*}{0.03} \\
\hline$\leq \mathbf{8}$ & 33 & 29.5 & 79 & 70.5 & & \\
\hline$>8$ & 83 & 41.3 & 118 & 58.7 & & \\
\hline \multicolumn{5}{|c|}{ Gestational age at appearance of HG: Mean \pm SD } & \multirow[t]{3}{*}{0.7} & \multirow[t]{3}{*}{0.3} \\
\hline$\leq 6$ & 62 & 35.0 & 115 & 65.0 & & \\
\hline$>6$ & 54 & 39.7 & 82 & 60.3 & & \\
\hline
\end{tabular}

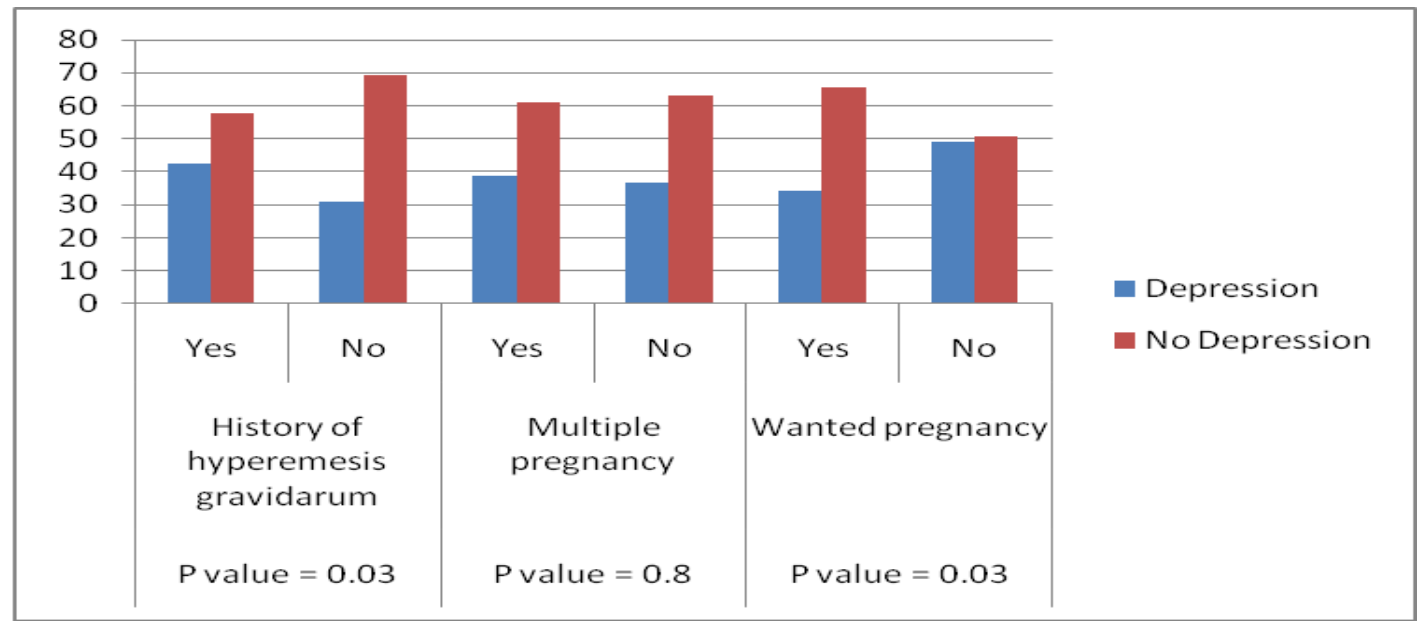


Figure 1. Percentages distribution of obstetric history of Hyperemesis Gravidarum women according to depression status.

Table 4. Distribution of characteristics means of Hyperemesis Gravidarum women according to depression status.

\begin{tabular}{|l|c|c|c|c|}
\hline Variable & $\begin{array}{c}\text { Depression } \\
\text { Mean } \pm \text { SD }\end{array}$ & $\begin{array}{c}\text { No depression } \\
\text { Mean } \pm \text { SD }\end{array}$ & & \\
\hline Age (years) & $27.1 \pm 6.7$ & $27.1 \pm 6$ & 0.03 & 0.1 \\
\hline Socioeconomic & $4.1 \pm 0.8$ & $3.6 \pm 0.8$ & 2.1 & $\mathbf{0 . 0 0 1}$ \\
\hline Gravida & $4 \pm 2$ & $3 \pm 1$ & 2.1 & $\mathbf{0 . 0 3}$ \\
\hline Parity & $2 \pm 2$ & $2 \pm 1$ & 1.8 & 0.07 \\
\hline GA (weeks) at & $9.6 \pm 2.2$ & $9.4 \pm 3.2$ & 0.6 & 0.5 \\
\hline GA(weeks)at & $6.6 \pm 2$ & $6.1 \pm 2.6$ & 1.8 & 0.06 \\
\hline Miscarriage & $1 \pm 2$ & $1 \pm 1$ & 1.6 & 0.09 \\
\hline
\end{tabular}

\section{Discussion}

World Health Organization (WHO) states that the main $\mathrm{HG}$ risk factors are stress, social relationships, stressful life events, anxiety and depression.${ }^{15}$ Despite that, a few researches were done to discover the prevalence and relations of psychopathological factors which accompany the pregnancy. ${ }^{16}$

This study reported a prevalence of depression among early pregnant women with hyperemesis gravidarum was $37.1 \%$. This is lower than that reported by the previous study in Turkey $(53.9 \%)$ 17 , and higher than that reported by a Malaysian study $(19 \%)^{18}$, and an Omani $\operatorname{study}(24.3 \%)^{19}$. These differences in depression prevalence among HG pregnant women from our study might be attributed to discrepancies in lifestyle and cultural

habits, socioeconomic status and general mental health in the community in addition to the differences in studying designs and depression scores among studies. Our finding in the current study like the findings of the Turkish study ${ }^{20}$ which reported a significant association between high socioeconomic level and depression during early pregnancy, and this finding inconsistent with USA study $^{21}$ and Tanzania study ${ }^{22}$. This study reported a significant association between increased gestational age at time of interview and depression $(\mathrm{p}=0.03)$ which consistent with the findings of the Egyptian study ${ }^{23}$, and inconsistent with that of the USA study ${ }^{24}$. Like 


\section{Email:utjmed@utq.edu.iq}

the findings of an Indian ${ }^{25}$ studies which reported a significantly higher gravida mean among depressed pregnant than non- depressed pregnant which was similar to findings of the current study, and this finding inconsistent with the Turkish study ${ }^{26}$. Similar to current study findings, a Turkish study ${ }^{27}$ reported significant association between previous history of $\mathrm{HG}$ and development of depression during pregnancy. Pregnant women with HG who do not wanted pregnancy in the present study had higher depression prevalence $(\mathrm{p}=0.03)$. This is consistent with results of the previous studies carried out in Finland $^{28}$. In many literatures, unwanted pregnancy was considered as a precursor of depression and $\mathrm{HG}^{29}$, 30 ,in other studies it was considered as an outcome of depressive symptoms and HG in early pregnancy.$^{31}$

\section{Conclusions}

and

\section{Recommendations}

- About one-third (37.1\%) of pregnant women with hyperemesis gravidarum in Thi-Qar Maternity hospitals found to had depression. Although this rate was high on the provincial level, but it was consistent with a previous study conducted at another province in the country.

- For that reason it is recommended to:

1. Implement mental health care programs targeting pregnant women through the antenatal care services provided at the primary health care level.

2. National campaign and educational programs for early
Web Site: https://jmed.utq.edu.iq

detection of depression before and during early pregnancy to mitigate the impact of this disease on the mother and her fetus.

3. Large sized longitudinal studies on the relationship between depression and hyperemesis gravidarum in early pregnancy must be supported at the country level.

4. The awareness of medical Personal about depression among pregnant women should be raised.

5. The family Planning activities to mitigate unwanted Pregnancy must be reinforced.

\section{References}

1. Edmonds DK. Dewhurst's Textbook of Obstetrics \& Gynaecology. Oxford, UK: Blackwell Publishing;2007. P 1-717.

2. Flaxman SM, Sherman PW. Morning sickness: a mechanism for protecting mother and embryo. Q Rev

Biol 2000; 75(2):113-48.

3.McCarthy FP, Lutomski JE, Greene RA. Hyperemesis gravidarum: current perspectives. Int $\mathrm{J}$ Womens Health 2014; 6:719-25.

4.Akiskal HS. Mood disorders: Clinical features. In Sadock BJ sadock VA,Ruiz P.EDS. Kaplan and Sadock's Comprehensive Textbook of Psychiatry, 9th ed. VOL.1. Philadelphia: Lippincott Williams and Wilkins. 2009; pp. 1693-1733.

5. Milanović SM, Erjavec K, Poljičanin T, Vrabec B, Brečić P. Prevalence of depression symptoms and associated socio-demographic factors in primary health care patients. 


\section{Email:utjmed@utq.edu.iq}

Psychiatria Danubina, 2015; 27(1): pp 31-7.

6. Wissart J, Parshad O, Kulkarni S. Prevalence of pre- and postpartum depression in Jamaican women. BMC Pregnancy Childbirth. 2005;5:15.

7. Bennett HA, Einarson A ,Taddio A, Koren G, Einarson TR. Prevalence of depression during pregnancy: Systematic review. Obst \& Gyn. 2004;103(4):698-709.

8. Jabbour S, Giacaman R, Khawaja M, Nuwahid I, editors. Public Health in the Arab World. First Edit. Cambridge University Press, 2012; $\mathrm{P} ; 258$.

9. Bennett HA, Einarson A, Taddio A, Koren G, Einarson TR. Prevalence of depression during pregnancy: Systematic review. Obst. \& Gyn. 2004;103(4):698-709.

10. FarisS.Depressionstatistics. $28^{\text {th }}$ ,2012.Retrievedfrom:

www.Healthline.com/Health/Depressi on/Statistics.

11. Biaggi A, Conroy S, Pawlby S, Pariante CM. Identifying the women at risk of antenatal anxiety and depression: A systematic review. Journal of Affective Disorders. 2016; 191:62-77.

12. Al-Asadi JN, Hussein ZB. Depression among infertile women in Basrah, Iraq: Prevalence and risk factors. J Chinese Med Assoc. 2015;78:673-7. 13.Charan J, biswas T. how to calculate sample size for different study designs in medical
Web Site: https://imed.utq.edu.iq

research. Indian j Psychol Med 2013; 35(2): 121-6.

14.Ghareeb AG. Manual of Arabic BDI-II. Alongo Press. Cairo Inventory: the author's twenty-five years of evaluation. Clin Psychol Rev 2000;8:77-100.

15.Solar O, Irwin A. A conceptual framework for action on the social determinants of health. Geneva: World Health Organization; 2010.P:1-65.

16.Chung TK, Lau TK, Yip AS, Chiu HF, Lee DT. Antepartum depressive symptomatology is associated with adverse obstetric and neonatal outcomes. Psychosomatic Medicine 2001; 63(5):830-4.

17.Aksoy H, Aksoy Ü, Karadağ Öİ, Hacimusalar Y, Açmaz G, Aykut G, et al. Depression levels in patients with hyperemesis gravidarum: a prospective case-control study. Springerplus $2015 ; 4: 2-7$.

18.Tan PC, Zaidi SN, Azmi N, Omar SZ, Khong SY. Depression, Anxiety, Stress and Hyperemesis Gravidarum: Temporal and Case Controlled Correlates. PLoS ONE 2014; 9(3):e92036

19.Al-Azri M, Al-Lawati I, AlKiyumi M, Al-Rawahi A, Davidson $\mathrm{R}$, Al-Maniri A. prevalence and risk factors of antenatal depression among Omani women in primary care setting. Sultan Qaboos Univ Med J. 2016;16(1):e35-e41. 


\section{Email:utjmed@utq.edu.iq}

20.Kamalak Z, Köüş N, Köüş A, Hizli D, Ayrim A, Kurt G. Is there any effect of demographic features on development of hyperemesis gravidarum in the Turkish population? Turk J Med Sci .2013 ;43: 995-9.

21.Goyal D, Gay C, Lee KA. How much does Low Socioeconomic Status Increase the Risk of Prenatal and Postpartum Depressive Symptoms in First Time Mothers? Women's health issues : official publication of the Jacobs Institute of Women's Health 2010; 20(2):96-104.

22.Rwakarema M, Premji SS, Nyanza EC, Riziki P, Palacios-Derflingher L. Antenatal depression is associated with pregnancy-related anxiety, partner relations, and wealth in women in Northern Tanzania: a cross-sectional study.BMC Women's Health 2015; 15:68.

23. Sabri Y, Nabel H. The impact of anxiety and depression during pregnancy on fetal growth and the birth outcome. Egyptian Journal of Psychiatry 2015; 36 (2): 95-100.

24.Schetter DC, Tanner L. Anxiety, depression and stress in pregnancy: implications for mothers, children, research, and practice. Current opinion in psychiatry 2012; 25(2):141-8.

25.Ajinkya S, Jadhav PR, Srivastava NN. Depression during pregnancy: Prevalence and obstetric risk factors
Web Site: https://imed.utq.edu.iq

among pregnant women attending a tertiary care hospital in Navi Mumbai. Industrial Psychiatry Journal. 2013; 22(1):37-40.

26.Kamalak Z, Köüş N, Köűş A, Hizli D, Ayrim A, Kurt G. Is there any effect of demographic features on development of hyperemesis gravidarum in the Turkish population? Turk J Med Sci.2013; 43: 995-9.

27.Hizli, D., Kamalak, Z., Kosus, A., Kosus, N., \& Akkurt, G. Hyperemesis gravidarum and depression in pregnancy: is there an association? Journal of Psychosomatic Obstetrics and Gynaecology. 2012;33(4): 171-5.

28.Räisänen S, Lehto SM, Nielsen HS, Gissler M, Kramer MR, Heinonen S. Risk factors for and perinatal outcomes of major depression during pregnancy: a population-based analysis during 2002-2010 in Finland. BMJ Open 2014; 4:e004883.

29.Benute GRG, Nomura RMY, Siracuza RJ, Fraguas Jr R, Lucia MCS, Zugaib M. Depression during pregnancy in women with a medical disorder: risk factors and perinatal outcomes. Clinics 2010; 65(11):112731.

30.Lee NM, Saha S. Nausea and vomiting of pregnancy. Gastroenterol Clin North Am [Internet]. 2011 Jun;40(2):309-34, vii.

31.Christensen AL, Stuart EA, Perry DF, Le H-N. Unintended pregnancy and perinatal depression trajectories in 
Email:utjmed@utq.edu.iq

low-income, high-risk Hispanic immigrants.Prevention science: the official journal of the Society for
Web Site: $\underline{\text { https://imed.utq.edu.iq }}$

Prevention Research 2011; 12(3):28999.

\section{نسبة انتشار مرض الكآبة بين النساء الحوامل اللواتي يعانين من

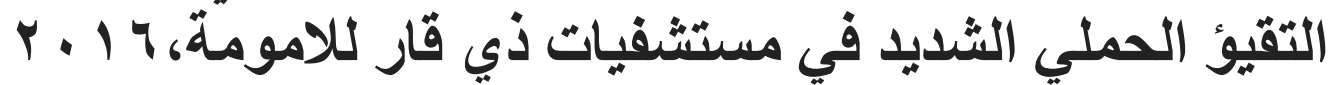

احمد حسن حسين

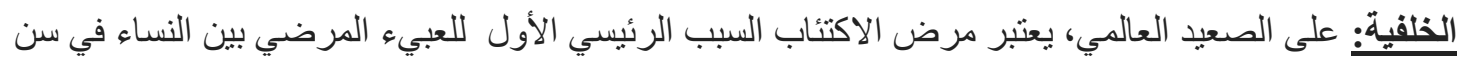

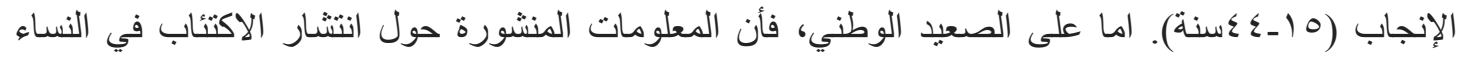

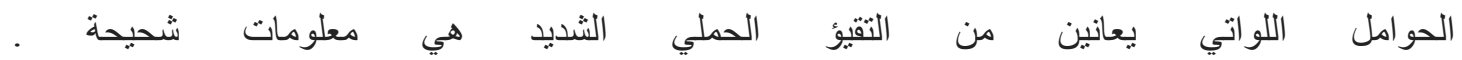

الأهداف: تم إجر اء هذه الدر اسة لقياس مدى انتشار الاكتئاب بين النساء الحو امل اللواتي يعانين من التقيء الحملي الثنديد

الطرائقي: تعتبر هذه الدر اسة دراسة مقطعية منفذة في اثنان من المستشفيات التعليمية لمحافظة ذي قار ( مستشفى التئي

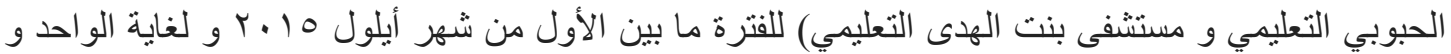

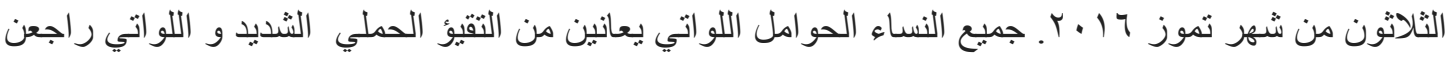

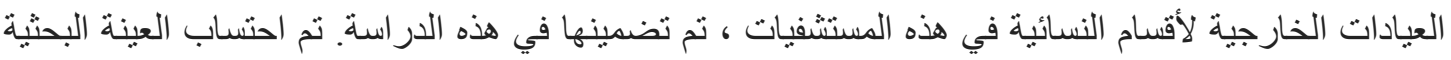

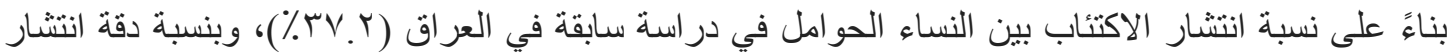

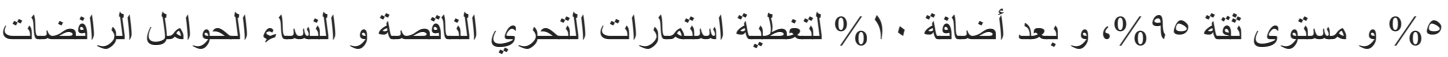

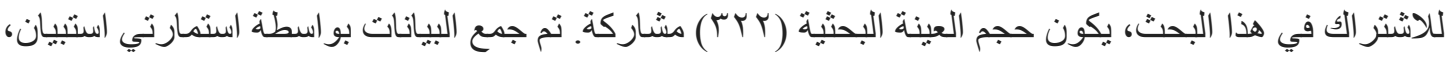

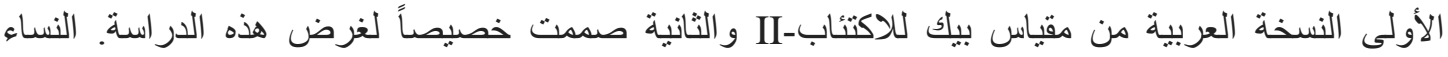

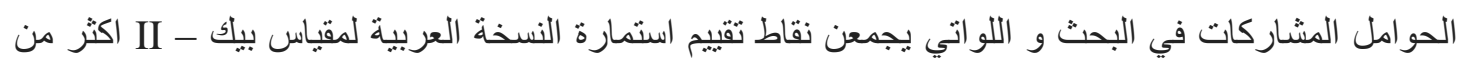
نقطة،

النتائج: تبين هذه الدراسة أن معدل انتشار الاكتئاب بين النساء الحوامل اللو اتي يعانين من التقيؤ الحملي الثنديد التئي

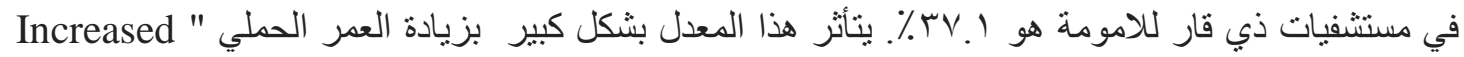

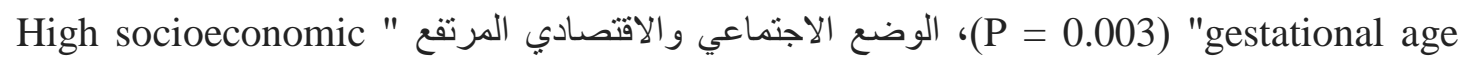
previous history of "status P = ) "Unwanted pregnancy" "Hyperemesis gravidarum
( $\mathrm{P} \quad=$
$0.03)$
"Gravidity"
الحمل الحمل
مرات
وزيادة عدد
‘(0.03 
Thi-Qar Medical Journal (TQMJ): Vol.(13), No.(1), 2017

Email:utjmed@utq.edu.iq

Web Site: $\underline{\text { https://imed.utq.edu.iq }}$

الاستنتاجات و التوصيات: ثلث النساء الحوامل اللواتي يعانين من التقيؤ الحملي الثنديد في مستشفيات ذي قار التهار

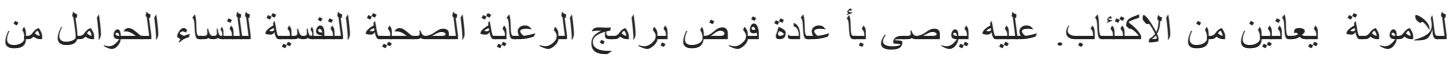

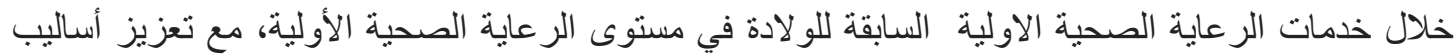

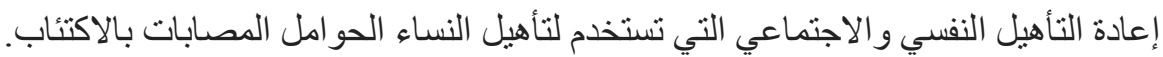

